\section{Hemodynamic Effects of Atracurium and Cisatracurium and the Use of Diphenhydramine and Cimetidine}

Claudia Maria Nogueira Correa, M.D., Gisele Zapata Sudo, M.D., and Roberto Takashi Sudo, M.D.

\section{INTRODUCTION}

The incidence of anaphylaxis during anesthesia ranges from 1:6,000 to $1: 20,000$ anesthetic procedures, and any drug can potentially produce hypersensitivity reactions. Neuromuscular blockers, latex, and antibiotics are frequently involved in those reactions ${ }^{1}$. The mortality of anaphylactic shock varies from $3 \%$ to $6 \%^{2}$.

Anaphylactic and anaphylactoid reactions cannot be discriminated clinically, since the only difference relies on the mechanisms of histamine release 1,3 . In anaphylactic reactions $\mathrm{IgE}$ binds to the surface of mast cells, while in anaphylactoid reactions histamine is released directly or through activation of the complement ${ }^{3}$. Anaphylactoid reactions account for $30 \%$ to $40 \%$ of hypersensitivity reactions ${ }^{1}$.

Neuromuscular blockers (NMB) are the main cause of intraoperative anaphylaxis, being responsible for $50 \%$ to $70 \%$ of the cases during anesthesia ${ }^{1}$. As a rule, benzylisoquinoline compounds promote the non-immunologic release of histamine that can cause a reduction in systemic blood pressure and bronchoconstriction in susceptible patients ${ }^{4}$.
Atracurium, a benzylisoquinoline compound, is a non-depolarizing blocker of neuromuscular cholinergic receptors ${ }^{5}$. It is composed by a mixture of ten optical and geometrical isomers ${ }^{5,6}$. The incidence of atracurium-related hypotension is low, but it has been considered the etiologic factor in $18 \%$ of the episodes of anaphylaxis during anesthesia ${ }^{2}$. In doses higher than three times its $\mathrm{ED}_{95}$ in humans, this drug can cause severe hypotension 5,6 . Cisatracurium, one of the 10 isomers of atracurium, has a similar profile, since evidence that isomers have a different behavior on the release of histamine does not exist ${ }^{3}$.

The objective of the present study was to compare the hemodynamic effects of the intravenous administration of different doses of atracurium and cisatracurium in rats, and to investigate whether histamine receptor blockers, $\mathrm{H} 1$ (diphenhydramine) and $\mathrm{H} 2$ (cimetidine), protect against those hemodynamic changes. The use of diphenhydramine and cimetidine as $\mathrm{H} 1$ and $\mathrm{H} 2$ antagonists, respectively, was based on literature reports suggesting that those substances could block atracurium-induced hemodynamic actions 7,8 .

\section{METHODS}

All experimental protocols used in the present study were approved by the Ethics on Animal Use Commission of the Health Sciences Center of the Universidade Federal do Rio de Janeiro (CCS-UFRJ). This study was undertaken in three steps:

\section{1) In vivo assessment of the neuromuscular blockade}

Wistar Rats of both genders, weighing 300 to $450 \mathrm{~g}$, were used to determine the dose necessary to promote neuromuscular blockade in rats.

Animals were anesthetized with $50 \mathrm{mg} \cdot \mathrm{kg}^{-1}$ of intraperitoneal sodium pentothal. The animals were intubated and the lungs were ventilated with room air with an automatic Harvard ventilator for small animals. To achieve adequate respiratory conditions, tidal volume was maintained at $10 \mathrm{ml} . \mathrm{kg}^{-1}$ and a respiratory rate of $50 \mathrm{bpm}$ (breaths per minute).

To investigate the in vivo effects of NMBs, the technique described by Brown et al. in $1936{ }^{9}$ was used. The sciatic nerve of one of the paws was surgically dissected and stimulated with a pair of platinum electrodes connected to a Grass S88 stimulator. The tendon of the gastrocnemius muscle was fixed to the Grass FT03 transducer with a metallic string and contractions were recorded on paper with a quill. The voltage of the stimuli and muscle stretching were adjusted to obtain maximal muscular contractions, i.e., until stimuli frequency that promoted maximal muscular contraction were achieved, which was $0.2 \mathrm{~Hz}$. Thus, supramaximal stimuli were evoked to assess the neuromuscular function under the effects of the intravenous administration of atracurium or cisatracurium. Train-of-four (TOF) stimuli of $2 \mathrm{~Hz}$ were used to determine the occupation rate of nicotinic receptors in the muscle and to evaluate the neuromuscular function in experimental animal models, since the relationship between 
the first (T1) and fourth (T4) TOF stimuli is considered the most sensitive index to detect non-depolarizing neuromuscular block ${ }^{10-12}$. The T4/T1 ratio was calculated by dividing the amplitude of the fourth stimulus, in centimeters, by the amplitude of the first stimulus $(\mathrm{cm})$, and the result was expressed in percentage ${ }^{11}$.

The right internal jugular vein was dissected and a P-10 silicon catheter was inserted for the intravenous administration of the NMBs.

The left internal carotid artery was dissected and a P-30 silicon catheter was inserted, filled with NS and heparin (50 IU. $\mathrm{mL}^{-1}$ ) to monitor the blood pressure (BP). The catheter was connected to a Statham pressure transducer and the blood pressure was recorded continuously by the model 7 Grass polygraph by a metallic quill on paper. The blood pressure was monitored to observe the hemodynamic response to atracurium and cisatracurium.

The effects of atracurium and cisatracurium on neuromuscular function were evaluated by intermittent intravenous bolus injections of both drugs. They were administered until complete inhibition of neuromuscular function was achieved, which was considered as equal or greater than $95 \%$ of the T4/T1 ration $^{12}$. The interval between doses was the one that allowed complete clinical recovery of the neuromuscular function (95\% T4/T1 ratio). For atracurium, we started with $200 \mu \mathrm{g} . \mathrm{kg}^{-1}$ with subsequent doses of $200 \mu \mathrm{g} \cdot \mathrm{kg}^{-1}$; for cisatracurium, the initial dose was $50 \mu \mathrm{g} \cdot \mathrm{kg}^{-1}$ with increments of $50 \mu \mathrm{g} \cdot \mathrm{kg}^{-1}$.

Atracurium was used in 12 animals, while 10 animals were used for cisatracurium.

Neuromuscular function was chosen as parameter to repeat the doses of NMBs because the pharmacokinetics of atracurium and cisatracurium in rats is not known. Besides, some studies report that those neuromuscular blockers do not have cumulative effects when repeated doses are administered ${ }^{6,13}$.

Neuromuscular blockade dose-response curves were plotted based on the data obtained with different doses of atracurium and/or cisatracurium in relation to the values of TOF T4/T1. Linear regression was then used to calculate the $\mathrm{ED}_{50}$ (dose necessary to reduce the neuromuscular function by $50 \%$ or $50 \%$ of the $\mathrm{T} 4 / \mathrm{T} 1$ ratio) and $\mathrm{ED}_{95}$ (dose necessary to reduce the neuromuscular function by $95 \%$ or $95 \%$ of the T4/T1 ratio) of atracurium and cisatracurium.

At the end, the animals were sacrificed under anesthesia with sodium pentobarbital.

\section{2) Changes in blood pressure (BP) and heart rate (HR)}

To evaluate the effects of atracurium and cisatracurium on blood pressure, Wistar rats of both genders, weighing 300 to $450 \mathrm{~g}$, were prepared to record the blood pressure (BP) and heart rate (HR).

The animals were anesthetized with intraperitoneal pentobarbital 50 mg. $\mathrm{kg}^{-1}$ for the dissection of the right internal jugular vein and the left carotid artery. After dissection of the right internal jugular vein, a P-10 silicone catheter was inserted and filled with NS for the intravenous administration of NMBs.
The blood pressure (BP) was monitored by inserting a P-30 silicone catheter filled with heparinized $\left(50 \mathrm{IU} \cdot \mathrm{mL}^{-1}\right) \mathrm{NS}$ in the left carotid artery of the rats. The catheter was connected to a Statham pressure transducer and the pressure was recorded continuously on paper by a model 7 Grass polygraph. The electrocardiogram (ECG) was obtained by placing a pair of electrodes on the DI derivation and recorded by the Gould Brush 2400 . The heart rate (HR) was determined by the $R$ wave of the ECG (Figure 1).

To evaluate whether the intravenous administration of atracurium e cisatracurium promoted different responses in the blood pressure, four groups of four animals were used. The first group received an intravenous bolus of $1 \mathrm{mg}^{\mathrm{kg}}{ }^{-1}$ of atracurium; the second group received continuous intravenous infusion of atracurium; and the third and the fourth groups received intravenous cisatracurium, in bolus and continuous infusion, respectively.

As shown in figure 2, continuous infusions of $0.5 \mathrm{mg} . \mathrm{kg}^{-1}$ and $0.2 \mathrm{mg} \cdot \mathrm{kg}^{-1}$ of atracurium and cisatracurium, respectively, did not change the blood pressure. Those doses promoted a $95 \%$ blockade of the neuromuscular function. Continuous infusions with higher doses also did not promote significant changes in blood pressure. Thus, to compare the effects of those drugs on blood pressure, only the experiments with intravenous boluses were used.

To determine the effects of bolus doses of atracurium on the blood pressure, two groups of six animals, who received different doses, 1 mg. $\mathrm{kg}^{-1}$ (atracurium $\mathrm{ED}_{95}$ times one) and 4 mg. $\mathrm{kg}^{-1}$ (atracurium ED $\mathrm{D}_{95}$ times four), were used. Changes in systolic (SP), diastolic (DP), and mean arterial pressure (MAP) were evaluated. To assess the same effects of cisatracurium, three groups of four animals were used. The first group received $1 \times \mathrm{ED}_{95}\left(0.25 \mathrm{mg} \cdot \mathrm{kg}^{-1}\right)$ of cisatracurium, the second group received four times the $\mathrm{ED}_{95}\left(1 \mathrm{mg} \cdot \mathrm{kg}^{-1}\right)$, and the third group received 16 times $\mathrm{ED}_{95}\left(4 \mathrm{mg} \cdot \mathrm{kg}^{-1}\right)$. Changes in systolic (SP), diastolic (DP), and mean arterial pressure (MAP) were evaluated in all three groups.

The dose of $4 \mathrm{mg} \cdot \mathrm{kg}^{-1}$ of cisatracurium was used because the molecular weights of atracurium and cisatracurium are equal,

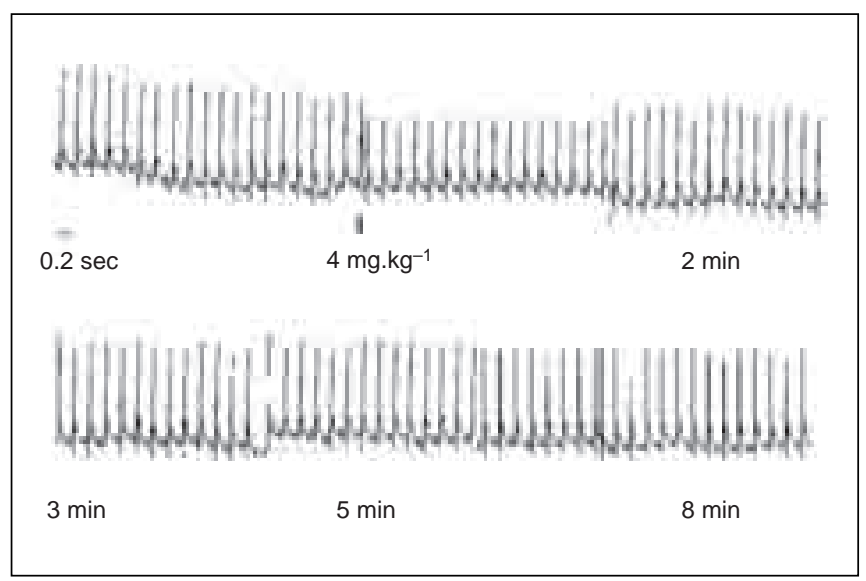

Figure 1 - Effects of atracurium on the ECG of the rats. Electrocardiogram of a rat, on DI derivation, during the intravenous administration of bolus doses of atracurium equivalent to $4 \times E_{95}$. 


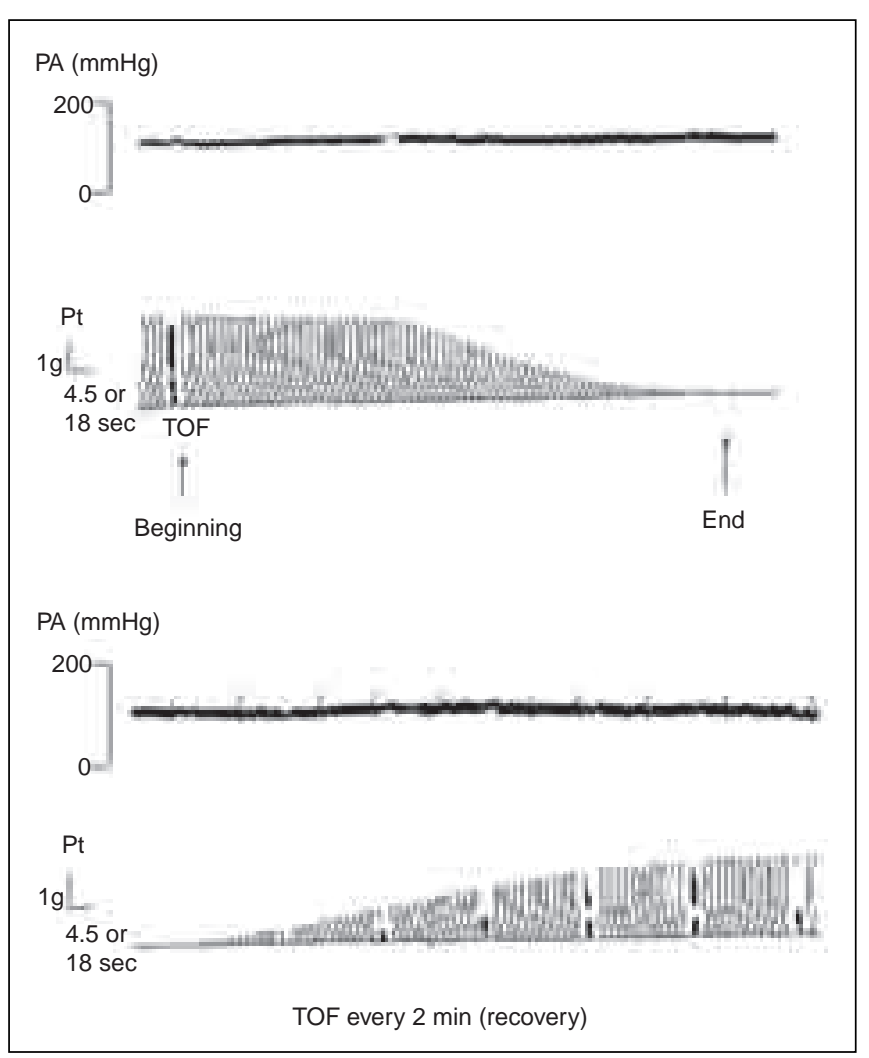

Figure 2 - Effects of the continuous infusion of atracurium on the neuromuscular function and blood pressure of rats. Recording of the effects of the intravenous infusion of atracurium $\left(0.5 \mathrm{mg} \cdot \mathrm{kg}^{-1}\right.$. $\mathrm{min}^{-1}$ ) on the blood pressure of rats and contraction (Pt) of the rat gastrocnemius muscle obtained by the electrical stimulation of the sciatic nerve. The arrows indicate the beginning and end of the infusion. The train of four was evaluated at the beginning and at 2-minute intervals after the discontinuation of the infusion. Similar results were observed for $0.2 \mathrm{mg} \cdot \mathrm{kg}^{-1} \cdot \mathrm{min}^{-1}$ of cisatracurium (nonequipotent doses). TOF $=$ train of four.

since they are isomers; therefore, by using the same molecular mass for each of the isomers, comparative evaluation of the release of histamine by each drug was possible.

The four-animal group for cisatracurium was considered satisfactory because, according to reports in the literature, cisatracurium promotes greater hemodynamic stability 5,6 .

A reduction in mean arterial pressure (MAP) higher than $20 \%$ was considered suggestive of histamine release.

At the end of the experiments, the animals were sacrificed under anesthesia with sodium pentobarbital.

\section{3) Use of Diphenhydramine, Cimetidine and Atracurium}

Wistar rats of both genders, weighing 300 to $450 \mathrm{~g}$, were prepared for the recording of the blood pressure $(\mathrm{BP})$ and heart rate $(\mathrm{HR})$.

After the determination of the doses of atracurium and cisatracurium that promote hypotension in rats, the third step of the investigation was undertaken to evaluate whether changes in blood pressure are mediated by the release of histamine. For such, $\mathrm{H} 1$ (diphenhydramine) and $\mathrm{H} 2$ (cimetidine) anti-histamines were used 7,8 .

The animals were anesthetized with the intraperitoneal admi-

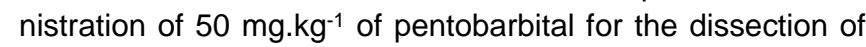
the right internal jugular vein and the left carotid artery. A P-10 silicone catheter filled with NS was inserted for the intravenous administration of NMBs.

Blood pressure (BP) was measured by the insertion of a P-30 silicone catheter, filled with heparinized $\left(50 \mathrm{IU} . \mathrm{mL}^{-1}\right) \mathrm{NS}$, inserted in the left carotid artery of the rats. The catheter was connected to the Statham pressure transducer and the blood pressure was recorded continuously in paper by a model 7 Grass polygraph. The electrocardiogram (ECG) was obtained by placing a pair of electrodes in the DI derivation and recorded by the Gould Brush 2400 galvanometer. The heart rate (HR) was determined by the R waves of the ECG.

The animals were divided in three groups: the first group $(n=6)$ was pre-treated with diphenhydramine $\left(2 \mathrm{mg} \cdot \mathrm{kg}^{-1}\right)$, the second group $(n=7)$ received cimetidine $\left(4 \mathrm{mg}^{\mathrm{kg}} \mathrm{k}^{-1}\right)$, and the third group ( $n=8$ ) received both histamine antagonists, diphenhydramine $\left(2 \mathrm{mg} \cdot \mathrm{kg}^{-1}\right)$ and cimetidine $\left(4 \mathrm{mg} \cdot \mathrm{kg}^{-1}\right)$. Initially, $4 \times \mathrm{ED}_{95}\left(4 \mathrm{mg} \cdot \mathrm{kg}^{-1}\right)$ of atracurium were administered to confirm the hypotensive effect of this drug with this dose and, therefore, the number of animals in the control group was the sum of all experiments. After complete recovery of the hemodynamic parameters (approximately one hour), the animals were treated with $\mathrm{H} 1$ (diphenhydramine, 2 mg. $\mathrm{kg}^{-1}$ ) and/or $\mathrm{H} 2$ (cimetidine 4 mg. $\mathrm{kg}^{-1}$ ) antagonists 30 minutes before another administration of $4 \mathrm{mg} \cdot \mathrm{kg}^{-1}$ of atracurium. This interval was necessary for the effective occupation of histamine receptors by the respective antagonists ${ }^{7,8}$. Atracurium and $\mathrm{H} 1$ (diphenhydramine) and $\mathrm{H} 2$ (cimetidine) antagonists were diluted in distilled water.

Since cisatracurium only promoted significant changes in mean arterial pressure (MAP) at a dose of 16 times $\mathrm{ED}_{95}$, and those doses are not used clinically, the effects of histamine receptor blockers were evaluated just with atracurium.

At the end of all experiments, the animals were sacrificed under anesthesia with sodium pentobarbital.

\section{Statistical Analysis}

Inhibitory doses $50\left(E_{50}\right)$ and $95\left(E_{95}\right)$ to promote neuromuscular blockade were estimated by linear regression.

The effects of atracurium and cisatracurium on the blood pressure were transformed in percentages of the control level to facilitate the statistical analysis of the charts. Since blood pressure levels referred to the same animal, before and after treatment with anti-histamines, paired statistical tests were used. It was considered that the results of the blood pressure evaluation followed normal distribution.

The Student $t$ test was used to determine whether atracurium and cisatracurium had significantly different effects on blood pressure.

To determine whether the blood pressure after the administration of atracurium differed significantly among the three 
groups pre-treated with diphenhydramine and cimetidine, ANOVA, with Newman-Keuls post-test, was used.

Differences were considered significant when $p$ was lower than $0.05(p<0.05)$.

\section{RESULTS}

\section{In vivo neuromuscular blockade - Dose response curves for neuromuscular blockade}

The results of the dose-response curves of inhibition of the neuromuscular function were: atracurium $\mathrm{ED}_{50}=430 \mathrm{mg} \cdot \mathrm{kg}^{-1}$ and $\mathrm{ED}_{95}=975 \mathrm{mg} \cdot \mathrm{kg}^{-1}$; cisatracurium $\mathrm{ED}_{50}=130 \mathrm{mg} \cdot \mathrm{kg}^{-1}$ and $\mathrm{ED}_{95}=232 \mathrm{mg} \cdot \mathrm{kg}^{-1}$ (Figure 3).

\section{Effects of atracurium and cisatracurium on blood pressure and heart rate}

It can be observed on Figure 4, the intravenous administration of bolus doses of atracurium and cisatracurium equivalent to $\mathrm{ED}_{95}$ did not change mean arterial pressure (MAP).

Significant changes in mean arterial pressure (MAP) were seen with doses four times $\mathrm{ED}_{95}$ of atracurium (a reduction in MAP to $62.8 \pm 4.5 \%, p<0.05$ Student $t$ test), but it was not observed with the same dose of cisatracurium.

Doses of $16 \mathrm{ED}_{95}$ of cisatracurium reduced blood pressure to $82.5 \pm 2.3 \%(p<0.05$, Student $t$ test). Unlike the blood pres-

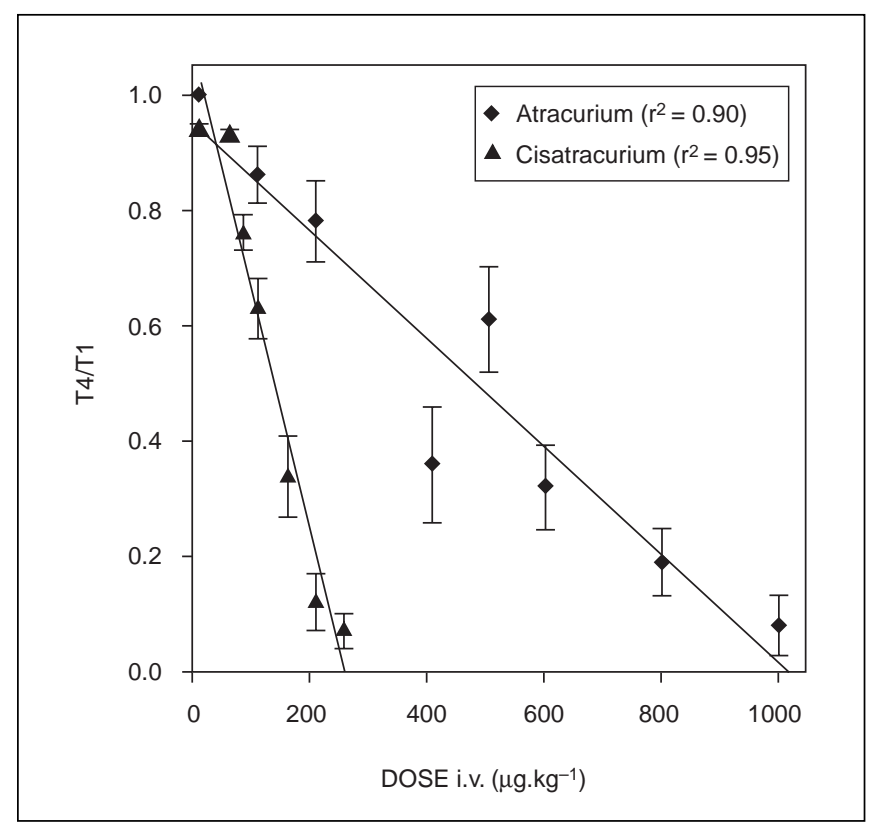

Figure 3 - Estimated doses of atracurium and cisatracurium in rats by linear regression. Inhibition of the neuromuscular transmission in rats. The markings in the chart represent mean \pm SEM of 12 experiments for atracurium and 10 for cisatracurium. $\mathrm{ED}_{50}$ and $\mathrm{ED}_{95}$ for both NMBs were obtained by linear regression analysis.Atracurium $\mathrm{ED}_{50}$ $=430 \mu \mathrm{g} \cdot \mathrm{kg}^{-1} ; \mathrm{ED}_{95}=975 \mu \mathrm{g} \cdot \mathrm{kg}^{-1} ;$ Cisatracurium $\mathrm{ED}_{50}=130 \mu \mathrm{g} \cdot \mathrm{kg}^{-1}$ and $\mathrm{ED}_{95}=232 \mu \mathrm{g} \cdot \mathrm{kg}^{-1} ; \mathrm{SEM}=$ Standard Error of the Mean. sure, the heart rate or the electrocardiogram pattern did not change after the bolus administration of atracurium or cisatracurium. The change in the amplitude of the $R$ wave observed shortly after the administration of atracurium (Figure 1) can be possibly explained by a shift in the electrical axis of the heart due to a reduction in afterload.

Figure 5 shows the changes in systolic (SP), diastolic (DP), and mean arterial pressure (MAP) promoted by $4 \mathrm{mg} \cdot \mathrm{kg}^{-1}$ of atracurium, and the hemodynamic protection provided by pretreating all three groups with diphenhydramine $\left(2 \mathrm{mg} \cdot \mathrm{kg}^{-1}\right)$, cimetidine (4 mg. $\left.\mathrm{kg}^{-1}\right)$, and diphenhydramine $\left(2 \mathrm{mg} \cdot \mathrm{kg}^{-1}\right)$ associated with cimetidine $\left(4 \mathrm{mg} \cdot \mathrm{kg}^{-1}\right)$. The administration of $4 \mathrm{mg} \cdot \mathrm{kg}^{-1}$ (four times the $E D_{95}$ ) of atracurium caused nonselective reduction in SP, DP, and MAP by $37 \%$ to $38 \%$. Prior treatment with diphenhydramine or cimetidine prevented partially the effects of atracurium on SP; however, SP did not change significantly, it still remained well below control levels $(95.4 \pm 2.5 \%)$, representing a $32 \%$ protection against the effects of atracurium ( $p<0.05$, Student $t$ test).

As for the effects of anti-histamines on DP, cimetidine was better than diphenhydramine. Thus, in the presence of diphenhydramine, DP was reduced from $62.7 \pm 4.7$ to $75 \pm 8.0 \%$ of control levels; this reduction in blood pressure was considered significant when compared to control levels ( $p<0.05$, Student $t$ test) (Figure $5 B)$. In the presence of cimetidine, DP was maintained at $82.7 \pm$ $8.4 \%$ of control levels, indicating a protection $(p<0.05$, Student $t$ test) against the hypotensive action of atracurium.

The combined effect on SP and DP reflected on MAP levels (Figure 5C). The combination of both agonists, diphenhydramine and cimetidine, administered simultaneously, was effective in preventing the hemodynamic effects of atracurium $(p<0.05$, ANOVA).

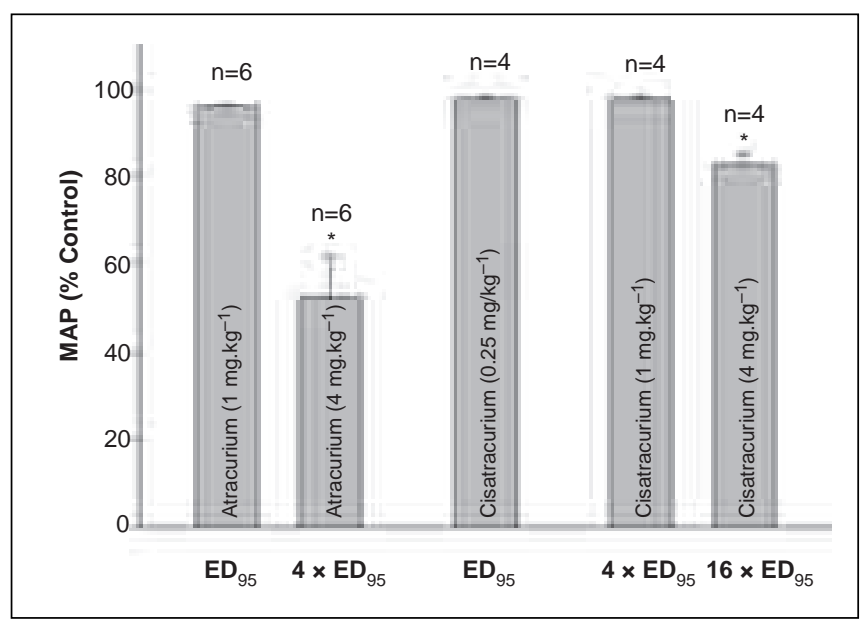

Figure 4 - Effects of atracurium and cisatracurium on the mean arterial pressure of rats. Effects of atracurium and cisatracurium on mean arterial pressure (MAP) of rats. Intravenous bolus doses multiples of the $E D_{95}$ were injected. The data represent mean \pm SEM. $\mathrm{N}=$ number of experiments. ${ }^{*} \mathrm{p}<0.05$ in relation to control (MAP for $1 \mathrm{mg} \cdot \mathrm{kg}^{-1}$ of atracurium). Paired bicaudal Student $t$ test for comparison between two groups. 


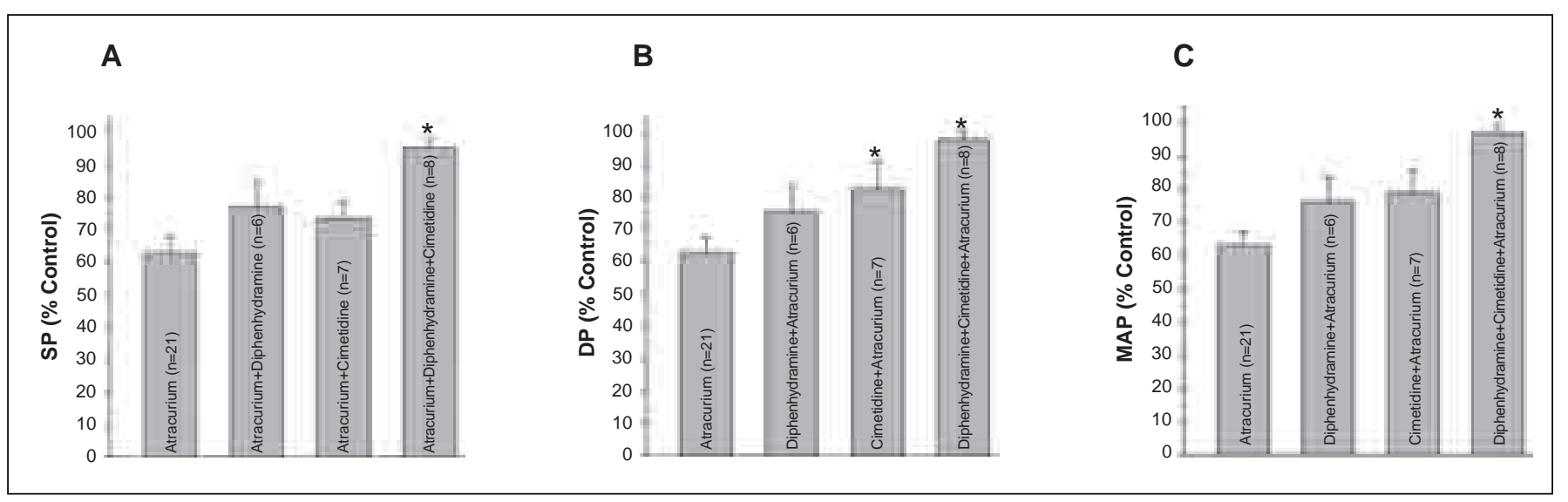

Figure 5 - Effects of pre-treatment with diphenhydramine and/or cimetidine on the effects of atracurium on the blood pressure of rats. Effects of 4 $x \mathrm{ED}_{95}$ of atracurium on SP, DP, and MAP of rats after pré-treatment with $\mathrm{H} 1$ (diphenhydramine $2 \mathrm{mg} \mathrm{kg}^{-1}$ ) and/or H2 (cimetidine $4 \mathrm{mg} \cdot \mathrm{kg}^{-1}$ ). A) On systolic blood pressure (SP). B) On diastolic blood pressure (DP). C) On mean arterial pressure (MAP). The data represent mean \pm SEM. $\mathrm{n}=$ number of experiments. ${ }^{*} \mathrm{p}<0,05$ in relation to atracurium. ANOVA for intergroup comparison and Newman-Keuls post-test.

\section{DISCUSSION}

Prior exposure to a neuromuscular blocker is not always necessary for the development of anaphylactic reaction, since $30 \%$ of the individuals with severe anaphylactic reactions to neuromuscular blockers have never been exposed to this type of drug ${ }^{3}$. It is believed that sensitization can result from the use of cosmetics, which have a quaternary ammonium group in their structure, explaining why anaphylactic reaction are three times more common in females than in males ${ }^{2,3}$.

Atracurium is a benzylisoquinoline neuromuscular blocker that causes hypotension when administered in doses equal or higher than three times $E D_{95} 5$ in humans. The severity of this effect depends on the dose and speed of administration ${ }^{13}$.

The release of histamine is the main mechanism responsible for the hemodynamic effects observed with benzylisoquinoline agents ${ }^{4,5}$ due to the presence of a quaternary ammonium ion in the molecule of neuromuscular blockers ${ }^{3}$. It is important to emphasize that the amount of histamine in mast cells and the susceptibility to its release by chemical agents depend on the species and tissues studied ${ }^{14}$.

The mechanism of histamine release triggered by any neuromuscular blocker (NMB) is not immunologically mediated ${ }^{15}$, since histamine release from mast cells induced by atracurium and vecuronium was not abolished by a reduction in temperature or absence of extracellular $\mathrm{Ca}^{2+17}$. Although in the present study the plasma concentration of histamine was not determined, a reduction in blood pressure as a function of the doses of atracurium and cisatracurium was observed. To characterize the role of histamine, $\mathrm{H} 1$ (diphenhydramine) and $\mathrm{H} 2$ (cimetidine) antagonists were administered to two groups of animals before the administration of atracurium, while a third group received a combination of both antagonists. In those experiments, it was evident that both receptors are involved in the hypotensive response ${ }^{16,18,19}$.

The need of combined blockade of both receptors indicates that hypotension triggered by histamine probably has two compo- nents: an immediate reduction in blood pressure mediated by $\mathrm{H} 1$ receptors, and a later reduction mediated by $\mathrm{H} 2$ receptors ${ }^{20,21}$. Those receptors can be found in the endothelium and smooth muscle cells, resulting in heterogeneous responses 20,21 .

From the results of this study, it is possible to state that the blockade of $\mathrm{H} 2$ receptors results in partial, but significant, protection of the diastolic pressure in rats, which might be explained by the presence of $\mathrm{H} 2$ receptors in the endothelium and smooth muscle ${ }^{21}$. Histamine probably causes hypotension by affecting different areas of the same site (blood vessel).

The anti-muscarinic effects of the $\mathrm{H} 1$ antagonist could explain the partial reversion of the reduction in blood pressure 19,23. The effects of the histamine released on available receptors would represent another possible explanation for the partial effect observed with one of the anti-histamines. Thus, when only one of the histamine receptors $(\mathrm{H} 1$ or $\mathrm{H} 2)$ is blocked, histamine would exert its action on free receptors, promoting an effect of equal magnitude to that observed in the absence of the antagonist ${ }^{20}$. Since $\mathrm{H} 1$ and $\mathrm{H} 2$ antagonists are competitive, higher doses of those antagonists could be necessary for more complete protection against hemodynamic changes; however, this could promote adverse reactions ${ }^{2,21}$.

As for the absence of any effects on the heart rate, $\mathrm{H} 1$ antagonists could have had a weak antimuscarinic effect 22,23 , besides the positive chronotropic and inotropic effects of histamine on non-blocked cardiac $\mathrm{H} 2$ receptors ${ }^{23}$. Other substances released by mast cell degranulation and implicated in development of hypotension would be the prostaglandins and tryptase ${ }^{20}$.

Thus, although the isomers have the same histamine-releasing property, atracurium was approximately four times more potent than cisatracurium in causing a significant reduction in blood pressure; therefore, cisatracurium provided better cardiovascular stability, even in doses much higher than the $E D_{95}$. Cisatracurium was a more potent neuromuscular blocker; then, it is possible that more potent neuromuscular blockers require a smaller number of molecules to exert their 
action and, consequently, release less histamine, with little clinical impact.

Under the conditions of the present study, isolate diphenhydramine and cimetidine did not prevent the reduction in mean arterial pressure induced by atracurium. However, the association of both drugs was effective in preventing the hemodynamic effects induced by atracurium. Cisatracurium, in the doses used in the present study, did not promote a reduction in blood pressure that would justify the use of preventive measures.

\section{ACKNOWLEDGEMENTS}

The authors would like to express their gratitude to Dr. Claudio Péricles of GlaxoSmithkline Brazil Ltda. for providing both compounds atracurium and cisatracurium. We are especially grateful to Margarete Manhães Trachez, Professor of the Universidade Federal Fluminense.

\section{REFERÊNCIAS - REFERENCES}

1. Mertes PM, Laxenaire MC. Allergy and anaphylaxis in anaesthesia. Minerva Anestesiol 2004;70:285-291.

2. Heier T, Guttormsen AB. Anaphylatic reactions during induction of anaesthesia using rocuronium for muscle relaxation: a report including 3 cases. Acta Anaesthesiol Scand 2000:44:775-781.

3. Toh KW, Deacoch SJ, Fawcett WJ. Severe anaphylactic reaction to cisatracurium. Anesth Analg 1999;88:462-464.

4. Basta SJ, Savarese JJ, Ali HH et al. Histamine-releasing potencies of atracurium, dimethyl tubocurarine and tubocurarine. $\mathrm{Br} \mathrm{J}$ Anaesth 1983;55:105s-106s

5. Lien CA, Belmont MR, Abalos A et al. The cardiovascular effects and histamine-releasing properties of 51W89 in patients receiving nitrous oxide/opioid barbiturate anesthesia. Anesthesiology 1995;82:1131-1138.

6. Wastila WB, Maehr RB, Turner GL et al. Comparative pharmacology of cisatracurium (51W89), atracurium, and five isomers in cats. Anesthesiology 1996;85:169-177.

7. Hosking MP, Lennon RL, Gronert GA. Combined $\mathrm{H}_{1}$ and $\mathrm{H}_{2}$ blockade attenuates the cardiovascular effects of high dose atracurium in rabbits. Life Sci 1989;44:347-353.

8. Hosking MP, Lennon RL, Gronert GA. Combined H1 and H2 receptor blockade attenuates the cardiovascular effects of high dose atracurium for rapid sequence endotracheal intubation. Anesth Analg 1988;67:1089-1092.

9. Brown GL, Dale HH, Feldberg W. Reactions of the normal mammalian muscle to acetylcholine and to eserine. J Physiol (London) 1936;87:394-424.

10. Ali HH, Savarese JJ. Monitoring of neuromuscular function. Anesthesiology 1976;45:216-249.

11. Ali HH, Savarese JJ, Lebowitz PW et al. Twitch, tetanus and trainof-four as indices of recovery from nondepolarizing neuromuscular blockade. Anesthesiology 1981;54:294-297.

12. Waud BE, Waud DR. The relation between the response to "train-offour" stimulation and receptor occlusion during competitive neuromuscular block. Anesthesiology 1972;37:413-416.

13. Belmont MR, Maehr RB, Wastila WB et al. Pharmacodynamics and pharmacokinetics of benzylisoquinolinium (curare-like) neuromuscular blocking drugs. Anesthesiol Clin North America 1993;11:251-281.

14. Stellato $C$, de Paulis A, Cirillo $R$ et al. Heterogeneity of human mast cells and basophils in response to muscle relaxants. Anesthesiology 1991;74:1078-1086.

15. Moss J, Rosow CE. Histamine release by narcotics and muscle relaxants in humans. Anesthesiology 1983;59:330-339.
16. Moss J, Rosow CE, Savarese JJ et al. Role of histamine in the hypotensive action of d-tubocurarine in humans. Anesthesiology 1981; 55:19-25.

17. Marone G, Stellato C, Mastronardi P et al. Mechanisms of activation of human mast cells and basophils by general anesthetic drugs. Ann Fr Anesth Reanim 1993;12:116-125.

18. Inada E, Philbin DM, Machaj V et al. Histamine antagonists and dtubocurarine induced hypotension in cardiac surgical patients. Clin Pharmacol Ther,1986;40:575-580.

19. Jooste E, Zhang Y, Emala CW. Neuromuscular blocking agents differential bronchoconstrictive potential in Guinea pig airways. Anesthesiology 2007;106:763-772.

20. Toda N, Konishi M, Miyazaki M. Involvement of endogenous prostaglandin $\mathrm{I} 2$ in the vascular action of histamine in dogs. J Pharmacol Exp Ther 1982;223:257-262.

21. Tayo F. Role of the endothelium and smooth muscle tone in the dilator response of the rabbit coeliac artery to histamine. J Pharm Pharmacol 1991;43:396-400.

22. Elbradie S. Neuromuscular efficacy and histamine-release hemodynamic changes produced by rocuronium versus atracurium: a comparative study. J Egypt Natl Canc Inst 2004;16:107-113.

23. Orzechowski RF, Currie DS, Valancius CA. Comparative anticholinergic activities of 10 histamine $\mathrm{H}_{1}$ receptor antagonists in two functional models. Eur J Pharmacol 2005;506:257-264.

\section{RESUMEN}

Correa CMN, Zapata-Sudo G, Sudo RT - Efectos Hemodinámicos del Atracurio y del Cisatracurio y el Uso de la Difenidramina y la Cimetidina.

JUSTIFICATIVA Y OBJETIVOS: Habida cuenta de que el atracurio puede causar hipotensión arterial en el hombre, se investigaron los efectos hemodinámicos promovidos por el atracurio y por el cisatracurio, y la protección hemodinámica dada por la difenidramina y la cimetidina en ratones.

MÉTODO: 1) Ratones Wistar anestesiados con pentobarbital sódico y preparados de acuerdo con Brown y col. para evaluar las dosis de atracurio y cisatracurio para la reducción de T4/T1 de la secuencia de cuatro estímulos mayor o igual al 95\%. 2) Evaluación de las alteraciones hemodinámicas del atracurio y el cisatracurio por inyección venosa, midiendo la presión arterial sistémica de la arteria carótida y electrocardiograma de ratones. 3) Observación de la protección hemodinámica por el tratamiento previo con difenidramina (2 $\left.\mathrm{mg} \cdot \mathrm{kg}^{-1}\right)$ y/o cimetidina (4 mg. $\mathrm{kg}^{-1}$ ) por inyección venosa. Análisis estadístico: test $t$ de Student, ANOVA.

RESULTADOS: El atracurio y el cisatracurio no modificaron la presión arterial promedio (PAP) en las dosis de $1 \mathrm{mg} . \mathrm{kg}^{-1}$ y $0,25 \mathrm{mg} . \mathrm{kg}^{-1}$, respectivamente. Las dosis de $4 \mathrm{mg}^{\mathrm{kg}}{ }^{-1}$ disminuyeron la PAP de $62,8 \pm 4,5 \%$ del control para el atracurio, y de $82,5 \pm 2,3 \%$ del control para el cisatracurio. Con la difenidramina y la cimetidina, la presión sistólica se redujo a 95,4 $\pm 2,5 \%$ del control. Con la cimetidina, la presión diastólica disminuyó $82,7 \pm 8,4 \%$ del control. El efecto conjunto sobre las presiones sistólica y diastólica se reflejó en los valores observados de la PAP.

CONCLUSIONES: La difenidramina y la cimetidina, aisladamente, no impidieron la disminución de la presión arterial promedio inducida por el atracurio. Sin embargo, la asociación de esos de los fármacos fue eficaz en la prevención de los efectos hemodinámicos inducidos por el atracurio. El cisatracurio, en las dosis del experimento, no promovió una disminución de la presión arterial que justificase las medidas preventivas aplicadas en los grupos donde se utilizó el atracurio. 